\title{
CORRELATION OF DIETARY FACTORS AND PHYSICAL ACTIVITIES WITH THE FORMATION OF RENAL STONES
}

\author{
MANZOOR-UL-MAHBUB ${ }^{1}$, AKM KHURSHIDUL ALAM ${ }^{2}$, SUDIP DAS GUTPA ${ }^{1}$, MD. MIZANUR RAHMAN, \\ MD. ZAHURUL HAQUE ${ }^{1}$, HOWLADER FAZLUL KARIM ${ }^{3}$
}

${ }^{1}$ Department of Urology, Sir Salimullah Medical College, Dhaka, Bangladesh, ${ }^{2}$ Department of Urology, Bangabandhu Sheikh Mujib Medical University, Dhaka, Bangladesh, ${ }^{3} \mathrm{NICRH}$, Mohakhali, Dhaka

\begin{abstract}
Objective: This study was undertaken to find out the roles of dietary factors and physical activities in the formation of renal stones in our socio-demographic conditions.

Methods: This cross-sectional analytical study was conducted among 70 patients from October 2011 to November 2012 in the department of SSMCMH and a few other private hospitals in Dhaka city. The study included all patients of either gender and all ages attending our out-patient department who were diagnosed to have renal stones. The dietary habits of the patients were explored by face to face interview using food frequency questionnaire (FFQ). The physical activities were evaluated by structured questionnaire, and the metabolic work-ups were done by urinalysis and blood analysis. The results were reviewed and analyzed with the help of SPSS 17.

Result: Out of 70 patients about one-third were female (31.4\%) and two-third were male (68.6\%). Most of the study people belonged to age group 40-50 years. Mean was 43.7 years with standard deviation of 10.28 years. One-fifth of the respondents did minimal activities (0-5 hrs/day), One -third moderate activities (5-10 hrs/day) and about half severe activities (10-15hrs/day). One-fifth did not take any table salt but about one-fourth indulged much (>half tsf/day) and more than half took excessive (> 1tsf/day) salt. About 57.1\% stone patients of the present study habitually have taken excessive salt, $24.3 \%$ patients took much salt and $18.6 \%$ used no added table salt. About one-third (37.71\%) of the patients took calcium, one-fourth (25.71\%) vitamin-D, one-fifth ascorbic acid and the rest had no supplementations. The patients having supplementations found to have more urinary levels of the corresponding supplements. More ingestion of green leafy vegetables and fruits and juices are associated with increased level of urinary oxalate. 24-hrs urinary oxalate level found to be associated with increased occurrence of renal stones. Most of the patients (64.3\%) ingested habitually inadequate amount of fluid.
\end{abstract}

Conclusion: The study showed some important observational facts in regard to the respondent's diet and physical activities. The dietary and lifestyle modifications can reduce urinary stone disease.

Key words: Renal stones, dietary factors.

Bangladesh J. Urol. 2015; 18(1): 23-27

\section{Introduction:}

Urinary stone disease is a systemic metabolic and recurrent disease. It is the third most common disease of the urinary tract, exceeded only by urinary tract infections and pathologic conditions of the prostate[1]. Urolithiasis affects $4 \%$ to $15 \%$ of the world population and the incidence is increasing, especially in Europe[2].

Correspondences: Manzoor-ul-Mahbub, Department of Urology, Sir Salimullah Medical College, Dhaka, Bangladesh. E-mail: manzoor.mahbub@gmail.com
Though there is no exact data about its prevalence in Bangladesh but the problem is quite common.

Dietary factors believed to play important roles in the formation of kidney stones[3]. However there remains much controversies about the type and amount of diet or nutrients in the formation of renal stones. The incidence of stones vary in relation to age and gender. In the past, high dietary calcium was suspected to increase the risk of calcium containing renal stones but later it was found that high intake of dietary calcium 
decreases the risk of stone formation [4]. One possible explanation of this is that the high intake of calcium reduces oxalate absorption and subsequent excretion by binding oxalate in the gastrointestinal tract. Urinary oxalate may be more important than urinary calcium in respect to the formation of calcium-oxalate crystals[5].

Uncertainty also remains about the association among many other dietary factors, such as vitamin C, magnesium, animal protein in the formation of renal stones. Early observational studies found no significant association between these nutrients and stone formation[6] but effects of vitamin $C$ and magnesium intake on urinary composition is compelling. A recent metabolic trial demonstrated that large doses of vitamin C supplementation result in an increased excretion of urinary oxalate, an important risk factor for calcium oxalate stone[7-8]. Magnesium supplementation may reduce the intestinal absorption of oxalate and diminish the urinary oxalate excretion[9]. Animal protein and potassium intake may also influence the risk of calcium stone formation. Ingested animal protein generates an acid load that increase urinary calcium excretion and reduces the excretion of citrate[10]. So dietary potassium restriction increases and potassium supplementation may decrease urinary calcium excretion[11].

Fluid intake and physical activities have roles in the formation of renal stones, The risk of nephrolithiasis is substantially greater in individuals residing in hot climates. The role of fluid intake inadequate to maintain normal hydration and relatively dilute urine has been implicated in this phenomenon. A urinary volume $<1400 \mathrm{ml} /$ day conveys increased risk of recurrence of stone formation[12].

The study aims to observe and correlate the impact of diets and physical activities of the patients in their sociodemographic conditions. The study also aims to achieve the knowledge that hopefully help the population in preventing or minimizing the incidence or recurrence of renal stones by appropriate modifications of risk factors related to diets and physical activities.

\section{Material and Method:}

A cross sectional analytical study was conducted among 70 patients from October 2011 to November 2012 in SSMC \& MH and some other private hospitals in Dhaka city. The study included all patients of either gender and all ages with who were diagnosed to have renal stones and were attending in the out-patient department in our hospitals. The patients with congenital urinary tract abnormalities and who are known metabolic disorder were excluded. The dietary habits of the patients were explored by face to face interview using food frequency Questionnaire. The physical activities were evaluated by structured questionnaire and were divided into three groups according to the hours of physical activities, namely sedentary (0-5 hrs/day), moderate (5$10 \mathrm{hrs} /$ day) and Severe (10-15 hrs/day). The metabolic work-up was done by urinalysis and blood analysis. The former included urinary calcium and Oxalate and the later Serum Calcium. Results were reviewed and analyzed with the help of SPSS17.

\section{Result:}

Table-I Shows the distribution of the respondents by age.

Table-I

Age distribution of the patients.

\begin{tabular}{lcc}
\hline Age in years & Frequency & Percentage \\
\hline $20-30$ & 8 & 11.43 \\
$30-40$ & 18 & 25.71 \\
$40-50$ & 29 & 41.43 \\
$50-60$ & 13 & 18.57 \\
$>60$ & 2 & 2.86 \\
\hline Total & 70 & 100.00 \\
\hline
\end{tabular}

Table-II Shown one-fifth of the patients did minimal activities (0-5hrs), one-third moderate activities (5-10hrs) and about half severe activities (10-15hrs)

Table-II

Distribution of patients by degree of physical activities (occupational).

\begin{tabular}{lcc}
\hline Types of physical activities & Frequency & Percentage \\
\hline Sedentary (0-5hrs/day) & 17 & 24.28 \\
Moderate (5-10hrs/day) & 22 & 31.44 \\
Severe (10-15 hrs/day) & 31 & 44.28 \\
\hline Totall & 70 & 100.00 \\
\hline
\end{tabular}

Table-III Shows that more ingestion of green leafy vegetables and juices are associated with increased level of urinary oxalate. 
Table-III

Levels of Serum Calcium \& Uric Acid and Urinary Calcium, Oxalate \& Uric Acid in relation to dietary items.

\begin{tabular}{lccccc}
\hline Dietary ltems & $\begin{array}{c}\text { S. Calcium } \\
\text { Level } \\
\text { (Mean) }\end{array}$ & $\begin{array}{c}24 \mathrm{hrs} \mathrm{U.} \\
\text { Calcium } \\
\text { Level } \\
\text { (Mean) }\end{array}$ & $\begin{array}{c}24 \mathrm{hrs} \mathrm{U.} \\
\text { Oxalate } \\
\text { Level } \\
\text { (Mean) }\end{array}$ & $\begin{array}{c}\text { S. Uric Acid } \\
\text { Level } \\
\text { (Mean) }\end{array}$ & $\begin{array}{c}24 \mathrm{hrs} \mathrm{U.} \\
\text { Uric Acid } \\
\text { Level } \\
\text { (Mean) }\end{array}$ \\
\hline Meat \& Meat Products & $12 \mathrm{mg} / \mathrm{dl}$ & $300 \mathrm{mg} / \mathrm{dl}$ & $45 \mathrm{mg} / \mathrm{dl}$ & $6.5 \mathrm{mg} / \mathrm{dl}$ & $600 \mathrm{mg} / \mathrm{dl}$ \\
Milk \& Milk Products & $10 \mathrm{mg} / \mathrm{dl}$ & $250 \mathrm{mg} / \mathrm{dl}$ & $47 \mathrm{mg} / \mathrm{dl}$ & $6 \mathrm{mg} / \mathrm{dl}$ & $600 \mathrm{mg} / \mathrm{dl}$ \\
Green Leafy Vegetables & $9 \mathrm{mg} / \mathrm{dl}$ & $270 \mathrm{mg} / \mathrm{dl}$ & $60 \mathrm{mg} / \mathrm{dl}$ & $6 \mathrm{mg} / \mathrm{dl}$ & $610 \mathrm{mg} / \mathrm{dl}$ \\
Fruits \& Juices & $10 \mathrm{mg} / \mathrm{dl}$ & $280 \mathrm{mg} / \mathrm{dl}$ & $65 \mathrm{mg} / \mathrm{dl}$ & $6 \mathrm{mg} / \mathrm{dl}$ & $580 \mathrm{mg} / \mathrm{dl}$ \\
\hline
\end{tabular}

Table-IV Show thatabout one third of respondents (35.71\%) took calcium, one-fourth (25.71\%) took vitamin-D, about one-fifth took ascorbic acid supplementations and one-fifth did not take any supplementations.

Table-IV

Distribution of Nephrolithiasis by dietary supplementaions

\begin{tabular}{lccccc}
\hline Supplements & S.Calcium & U,Calcium & U.Oxalate & Frequency & Percentage \\
\hline & level (mean) & level (mean) & level (mean) & & \\
Calcium & $11.5 \mathrm{mg} / \mathrm{dl}$ & $325 \mathrm{mg} / \mathrm{dl}$ & $45 \mathrm{mg} / \mathrm{dl}$ & 25 & 35.71 \\
Vitamin-D & $11.2 \mathrm{mg} / \mathrm{dl}$ & $320 \mathrm{mg} / \mathrm{dl}$ & $45 \mathrm{mg} / \mathrm{dl}$ & 18 & 25.71 \\
Vitamin-C & $9 \mathrm{mg} / \mathrm{dl}$ & $250 \mathrm{mg} / \mathrm{dl} 3250$ & $60 \mathrm{mg} / \mathrm{dl}$ & 12 & 17.14 \\
No Supplements & $9.2 \mathrm{mg} / \mathrm{dl}$ & $\mathrm{mg} / \mathrm{dl}$ & $40 \mathrm{mg} / \mathrm{dl}$ & 15 & 21.44 \\
\hline Total & & & 70 & 100.00 \\
\hline
\end{tabular}

Table-V Shows one-fifth did not take any table salt but about one-fourth took (more than half tsf/day) and more than half took excessive (more than 1stf/day) salt.

Table-V

Distribution of renal stones by table salt ingestion.

\begin{tabular}{lccc}
\hline Amount & $\begin{array}{c}\text { S.Sodium } \\
\text { level (mean) }\end{array}$ & Frequency & Percent \\
\hline No added salt & $137 \mathrm{mmol} / \mathrm{L}$ & 13 & 18.6 \\
More than half tsf/day & $146 \mathrm{mmol} / \mathrm{L}$ & 17 & 24.3 \\
More than 1 tsf/day & $150 \mathrm{mmol} / \mathrm{L}$ & 40 & 57.1 \\
\hline Total & & 70 & 100.00 \\
\hline
\end{tabular}

Table-VI Show most of the patients (64.3\%) ingested inadequate amount of fluid, normal ingestion was much less (21.5\%) excessive fluid intake was insignificant (4.2\%)

Table-VI

Distribution of Renal stone patients by fluid intake.

\begin{tabular}{lcc}
\hline Frequency of fluid intake & Frequency & Percentage \\
\hline Minimum & 23 & 32.90. \\
Less than normal & 22 & 31.40 \\
Normal & 15 & 21.50 \\
More than normal & 07 & 10.00 \\
Excessive & 03 & 4.20 \\
\hline Total & 70 & 100.00 \\
\hline
\end{tabular}

Table-VII Shows one third of the patients had (36.7\%) calcium oxalet stones, more than one fourth of respondents (27.1\%) had mixed stones and $12.9 \%$ had magnesium, ammonium phosphate stones, Calcium containing stones were the most (60\%).

Table-VII

Frequency of stones by composition

\begin{tabular}{lcc}
\hline Composition of stones & Frequency & Percentage \\
\hline Calcium Oxalate & 25 & 35.7 \\
Calcium Phosphate & 17 & 24.3 \\
Mixed & 19 & 27.1 \\
Magnesium Ammonium & 9 & 12.9 \\
Phosphate (MAP) & & \\
\hline Total & 70 & 100.00 \\
\hline
\end{tabular}

Discussion:

Diet, especially animal protein, green leafy vegetables, ascorbates, table salt and, the mode of physical 
activities are strongly suspected of increasing the risk of kidney stones. We therefore deemed that these risk factors require an examination in our socio-demographic conditions.

The studies of Borghi et al [13] Curhan et al. 1993 [4] suggested that normal or high dietary calcium intake significantly decreases the risk of calcium oxalate stone formation. In our study, the data collected from the FFQ revealed a similar fact. As most of the respondents $(92.8 \%)$ of this study ingested least amount or no dietary calcium.

Trinchieri et al. 2001 [14] described that the beneficial effects of a normal or high dietary calcium intake result from a significant reduction or restriction of intestinal oxalate absorption, lowering the fraction of freely available oxalate in the urine and thereby decreases the urinary crystallization risk for calcium oxalate. This concept is also established in our study as derived from FFQ. Because it was found most of the respondents $(92.8 \%)$ ingested least or no dietary calcium (milk and milk products). The diet of the most renal stone patients chronically lacked high calcium containing food. A misconception on the part of the patient was also revealed through the questionnaire - most of them believed that high calcium containing diet was responsible for renal stone formation.

However, the effect of dietary calcium was not demonstrable for calcium supplementation as was described by Curhan et al. 1997. The study of Sopasnthit and Stithan [15] shown that the overall effect of supplemental calcium may actually have an increased risk for renal stone formation, particularly if not taken with meals. This factor may also have some role in the formation of renal stones. The present study also have found there is significant statistical relationship between the calcium containing kidney stones and intake of supplemental calcium and vitamin D. In this study $30(42.85 \%)$ out of $42(60 \%)$ respondents with calcium stone had supplemental calcium without any regards to meals. In our study the respondents shown increase level of 24 hours urinary calcium and oxalate in relation to supplemental calcium, vitamin D, and ascorbic acid ingestion. These are known stone forming constituents. In this study the fact was evident because the study found a positive correlation between dietary supplements and the frequency of renal stone occurrence.

Kleenan et al. 1964 [16] showed that maneuvers which increase urinary sodium excretion also increase urinary calcium excretion and therefore offered that dietary sodium also could be a risk factor for kidney stone formation. In this study it was found that more than half of the respondents (57.1\%) took excessive (>1tsf/day) amount of table salt, one-fourth took much $(>1 / 2$ tsf/day) and about one-fifth did not take any added salt. The present study has found a positive correlation between the added salt and renal stone formation.

Robertson and Peacock [17] found that dietary animal protein and total protein intake were increased in a group of patients with recurrent kidney stones than with controls. They also suggested that at a very high levels of dietary protein, greater proportion of the population would be at risk of altered urinary composition that favors stone formation, and some would be particularly susceptible to stone formation. This finding is not evident in this present study, in which most of the respondents (85.7\%) took noticeably low amount of protein in their diets.

There is potential exaggeration of stone formation by physical activities. Mayor and Smith explained it by the low urine output from excessive sweating with ensuing rise in urinary concentration of stone forming salts. They also described that metabolic acidosis resulting from strenuous physical activities or exercise cause hypocitraturia, which is a known inhibitor of the crystallization of calcium salts in urine. In our study, one-fifth of the respondents did minimal activities (0$5 \mathrm{hrs} /$ day), one-third moderate activities (5-10 hrs/day) and about half severe activities (10-15 hrs/day). This study reflects positively the finding of Mayor and Smith regarding the role of physical activities in the formation of renal stones.

\section{Conclusion:}

This cross sectional hospital based study was conducted to find the correlation of diet and physical activities with the formation of renal stones in the respondents' in their own socio-demographic conditions. The study revealed some important observational facts in regard to the patients diets and physical activities. The most respondents habitually ingested least amount of dietary calcium, which reduces the incidence of nephrolithiasis, and possibly had its deleterious effect in stone formation. The fluid intake of most of the patients were inadequate, which may have contributed in their stone formation. A large number of patients indulged extra table salt which is a known risk factor for stone formation.

\section{Conflict of interest: None declared}




\section{References:}

1. Stoller ML, Bolton DM. 2000, Urinary stone Disease. In Tangaho EA, Mcaninih JW (eds), smith General Urology. $15^{\text {th }}$. Ed. Lange medical books/ McGraw-Hill, Sanfrancisco, pp291-320.

2. Bora kupeli, Irkilata L,Gourocak S, et al: Does tamsulosin enhance lower ureterel stone clearance ? Urology 64:1111-1115,2004.

3. Goldfarb S. Dietary factors in the pathogenesis and prophylaxis of calcium Nephrolithiasis, Kidney Int; 1988; 134: pp544-5.

4. Curhan GC, Willette WC, Rimn EB. A prospective study of Dietary calcium and other Nurients and the Risk of Symptomatic Kidney stones. N Eng. J Med; 1993; 328: pp838-9.

5. Borsatti A. Calcium oxalate Nephrolithiasis: Defective oxalate Transport, Kidney Int. 2002; 16: pp624-31.

6. Curhan GC. Dietary Calcium, dietary protein and kidney stone formation. Miner Electrlyte Metab; 1997; 23(3-6): pp261-264.

7. Traxer O, Huet B, Pak CY. Effect of Ascorbic Acid Consumption on Urinary Stones Risk Factors, J Urol; 2003; 397-99.

8. Robertson WG, Scurr DS, Bridge CM. Factors Influencing Crystallization of Calcium Oxalate in Urine. J Crystal Growth; 1981; 53: pp182.

9. Lindberg J, Harvey J, pak CY. Effect of Magnessium Citrate and Magnessium Oxide in the Crystallization of Calcium salt in Urine. J Urol; 1990; 163: pp248-51.

10. Kok DJ, Lestra JA, Doorenbos CJ. The Effects of Dietary Excess in Animal protein and Sodium on the Composition and the Crystallization Kinetci of Calcium Oxalate Monohydate in Urine of Healthy Men, J Clin Endocrinol Metab; 1990; 71: pp61-7.

11. Lemann J Jr, Willette WC, Stampfer MJ 1991, Pottassium Administration Reduces and Pottasium Deprivation Increases Urinary Calcium Excretion in Healthy Adults, Kidney Int; 1991; 39: pp973-9.

12. Strauss Al, Coe FL 1982. Factors that Predispose to relapse of Calcium Nephrolithiasis During Treatment. AM J Med; 1982; 72: pp17-23.

13. Borghi L, Meschi T. Comparison of two diets for the prevention of recurrent stones in idiopathic hypercalciuria.N Eng J Med; 2002; 346(2): 77-84.

14. Trinchieri A, Zeneth G, Lizzaro R. Effect of potential renal acid load of foods on calcium metabolism of renal calcium stone formers. Eur Urol; 2001; 39 (suppl 2): pp33-37.

15. Sopasanthit W, Stitchan W. Schedule of taking calciun supplement and the risk of nephrolithiasis. Kidney Int; 2004; 65 (s): pp1835-1841.

16. Kleenan CR, Bohannan J, Lion S, maxwell MH. Effect of variation in sodium intake on calcium excretion in normal humans. Proc Sol Exp Biol Med; 1964; 115: pp29-31.

17. Robertson WG, Peacock M, Marshal DH, clark $\mathrm{PB}$. Risk factors in calcium stone disease of the urinary tract, $\mathrm{Br} \mathrm{J}$ Urol; 1981; 50: pp449-454.

18. Sicner R, Ebert D, Nicolay C 2003, Dietary risk factors for hyperoxaluria in calcium oxalate stone formers. Kidney Int; 2003; 63: pp1037-1043.

Abbreviations:

FFQ-Food frequency questionnaire.

BMI-Basal Metabolic Index. 